In the Colorado Front Range, as in many other mountain areas, the distinction between "rock glaciers" and debris-laden ice glaciers or snow patches is largely artificial. Where modern glaciers are clean, there is a tendency to emphasize the uniqueness of glaciers that are buried beneath thick layers of insulating debris. The significance of the Colorado Front Range rock glaciers is not that they indicate a climate "not quite severe enough to produce or sustain ice glaciers" (Madole, 1972) but rather that the environment at the time of their formation favored both (I) glacierization and (2) extensive rockfall from cirque headwalls.

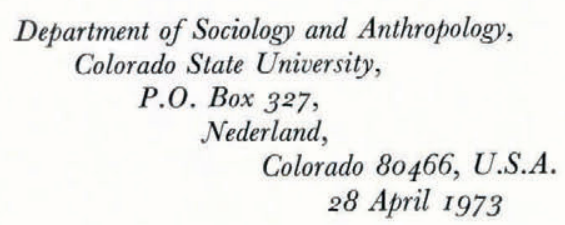

J. B. Benedict

\title{
REFERENCES
}

Carrara, P. E. 1973. Transition from shear moraines to rock glaciers. Journal of Glaciology, Vol. 12, No. 64,

p. 149. [Letter.]
Madole, R. F. 1972. Neoglacial facies in the Colorado Front Range. Arctic and Alpine Research, Vol. 4, No. 2,

p. 119-30.
Maher, L. J., jr. 1972. Absolute pollen diagram of Redrock Lake, Boulder County, Colorado. Quaternary Research, Vol. 2, No. 4, p. 53I-53.

Mudge, M. R. 1965. Rockfall-avalanche and rockslide-avalanche deposits at Sawtooth Ridge, Montana. Geological Society of America. Bulletin, Vol. 76, No. 9, p. $1003^{-14}$.

Outcalt, S. I., and Benedict, J. B. 1965 . Photo-interpretation of two types of rock glacier in the Colorado Front Range, U.S.A. Journal of Glaciology, Vol. 5 , No. 42, p. 849-56.

White, S. E. 1971. Rock glacier studies in the Colorado Front Range, 1961 to 1968. Arctic and Alpine Research, Vol. 3 , No. 1, p. $43^{-64}$.

SiR,

\section{Grain-size characteristics of superglacial dirt}

A large literature exists on superglacial sediment, particularly in relation to the development of dirt cones (Lewis, 1940; Sharp, 1949; Swithinbank, 1950; Lister, 1953; Pirrit, 1953; Streiff-Becker, 1954; McAllister, 1956; Krenek, 1958; Drewry, 1972) but rarely have the grain-size characteristics been described. Figure I illustrates the cumulative frequency curves for composite samples of superglacial sediment taken from three localities in the ablation zone of Østerdalsisen, an outlet glacier of the ice cap Svartisen in Norway (lat. $66^{\circ} 3 \mathrm{I}^{\prime} \mathrm{N}$., long. $14^{\circ} \mathrm{O} 7^{\prime} \mathrm{E}$.). The first sample is from a small dirt-cone field near the south-west margin of the glacier, where the average debris thickness on cone flanks was I $\mathrm{mm}$. The largest cone had a basal area of $2.2 \mathrm{~m}^{2}$ and a height of $0.45 \mathrm{~m}$, and was elliptical in plan, suggesting that the sediment had been deposited originally in a stream channel. The second is from a melt-water channel near the centre of the glacier, where sediment had accumulated in small holes which pitted the stream bed, and the third from the bottom of a shallow depression which was probably part of a former stream course and in which a dirt cone was in the process of formation. The ice core beneath the sediment was only $0.12 \mathrm{~m}$ above the surrounding glacier surface.

The similarity of the curves (Fig. I) suggests that the dirt in the three localities had a common origin and, together with the morphological characteristics of the deposits, that the sites represented different stages in dirt-cone formation. On a glacier such as Østerdalsisen, where the amount of superglacial dirt is small and the dirt is widely distributed, a means of sediment concentration is required if cones are to develop at all. Although there is general agreement that differential ablation of clean and debriscovered ice is the formative mechanism, different modes of dirt concentration have been proposed. Lewis (1940), Sharp (1949) and Swithinbank (1950) favoured deposition in melt-water streams and, although three samples cannot provide an adequate test of the hypothesis, the fact that the size-distribution curves for these sites of variable form and location are not significantly different does suggest a similar mode of concentration on Østerdalsisen. Highly localized deposition within superglacial streams could lead to the development of dirt cones even on glaciers with little surface dirt provided that sediment accumulates initially to a sufficient depth. 
The material is moderately sorted according to the verbal scale suggested by Folk and Ward (1957) for the inclusive graphic standard deviation, values of the parameter ranging from 0.72 to 0.80 . Nevertheless, the distribution curves are skewed towards the finer fraction with approximately $50 \%$ of the sediment being in the narrow coarse silt range. Drewry (1972), in one of the few detailed quantitative studies of dirt cones, has suggested that a threshold grain size of $0.2-0.6 \mathrm{~mm}$ exists for dirt-cone inception, below which no cones will develop because of the relatively low liquid limit of finer material. Less than

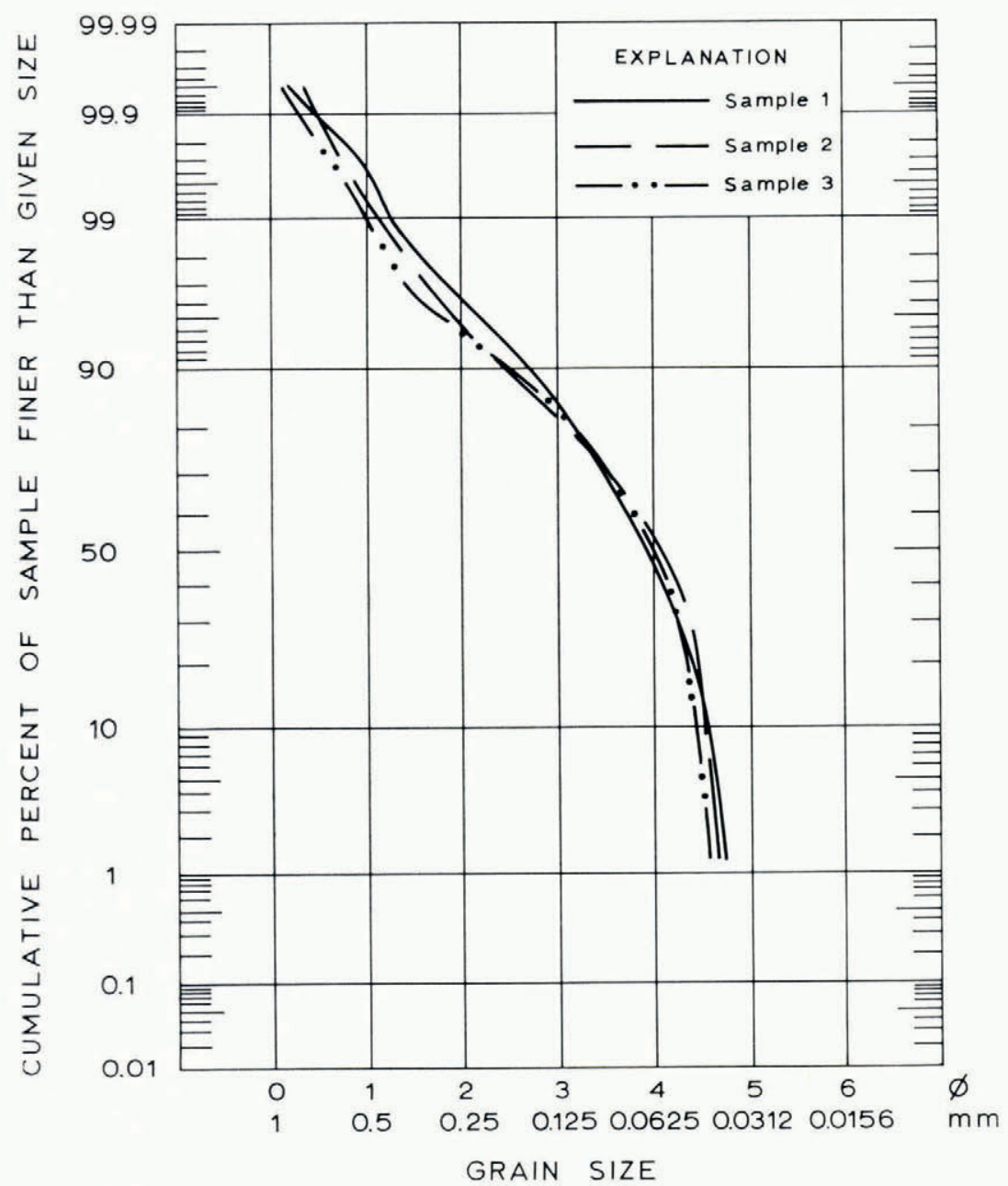

Fig. I. Cumulative frequency curves showing the size of material in a dirt-cone field (sample I), a fluvial deposit (sample 2) and an incipient dirt cone (sample 3 ).

$10 \%$ of the sample dirt from Østerdalsisen was coarser than $0.2 \mathrm{~mm}$ and yet dirt cones did form, albeit on a small scale. However, the small number of cones seemed to be related more to sediment availability than to sediment size. Although Drewry's experiments were carried out largely with well-sorted unimodal material, the limited evidence presented here does suggest that dirt cones can develop in finer sediment provided other conditions are favourable. Of these, the amount of melting and the degree of sediment saturation may be particularly important. Experiments with a wide range of sediment 
mixtures in a variety of micro-meteorological environments are required before critical sediment conditions can be defined with assurance.

Department of Geography,

University of Sheffield,

Sheffield $S_{I O}{ }_{2} T N$,

England

I4 March 1973

A. D. KNIGHTON

\section{REFERENCES}

Drewry, D. J. 1972. A quantitative assessment of dirt-cone dynamics. Fournal of Glaciology, Vol. I I, No. 63, p. $43 \mathrm{I}-46$.

Folk, R. L., and Ward, W. C. 1957. Brazos River bar: a study in the significance of grain size parameters. Journal of Sedimentary Petrology, Vol. 27, No. I, p. 3-26.

Krenek, L. O. 1958. The formation of dirt cones on Mount Ruapehu, New Zealand. Journal of Glaciology, Vol. 3, No. 24, p. 310, 312-14.

Lewis, W. V. 1940. Dirt cones on the northern margins of Vatnajoküll, Iceland. Fournal of Geomorphology, Vol. 3, No. 1 , p. $16-26$.

Lister, H. 1953. Report on glaciology at Breiðamerkurjökull, r95 r. Jökull, Ár 3, p. 23-3r.

McAllister, R. F. 1956. Unusual debris-covered ice cones from Umnak Island. Fournal of Glaciology, Vol. 2, No. 19, p. $631-33$.

Pirrit, J. 1953. The Scottish Iceland Expedition, 1952. Geographical Magazine, Vol. 26, No. 5, p. 235-43.

Sharp, R. P. 1949. Studies of superglacial debris on valley glaciers. American Journal of Science, Vol. 247, No. 5 , p. $289-315$.

Streiff-Becker, R. 1954. The initiation of dirt cones on snow: comments on J. Warren Wilson's paper. Journal of Glaciology, Vol. 2, No. 15, p. 365-66, 367.

Swithinbank, G. W. M. 1950. The origin of dirt cones on glaciers. Journal of Glaciology, Vol. I, No. 8, p. 439, $46 \mathrm{i}-65$.

SIR,

Antartic glacial surges?

In describing an ice delta in front of Northeast Glacier near Stonington Island, Marguerite Bay, Antarctic Peninsula, Antarctica, I wrote (Nichols, [1953], p. 88, 92-94, I96o, p. I442-43):

"The Northeast Glacier has a central zone up and down the glacier which is greatly crevassed. The areas marginal to this zone, however, have only a few narrow crevasses. An area of sea ice everywhere covered with fragments of glacial ice, found in front of the crevassed zone during the cold season, may be called a brash and growler ice delta. It extends from the barrier outward for hundreds of feet and is characterized by an irregular, hummocky topography and by indications of pressure (196o, fig. $12 ;$ pl. 4 , fig. 4) .... There is no area of broken glacial ice in front of the marginal zones. The brash and growler ice delta formed as follows: Masses of ice fell from the crevassed barrier onto the sea ice, and ice broke off from the glacial toe and floated upward ... . During and following this, the glacier continued to move forward and outward, pushing the ice fragments and sea ice in front of it. Later, another mass of ice fell from the barrier. The continuous forward motion of the glacier pushed this ice outward, while the fragments formed earlier were pushed still farther out ... . The thrust of the glacier as it moved into the field formed pressure ridges, cracks, and folded bay ice. Where the glacier moved most rapidly, the fragments were pushed farthest out into the bay and the area was widest. The delta was formed, therefore, by a discontinuous collapse of the crevassed barrier and by a rapid, continuous forward motion of the glacier while the barrier remained at essentially the same place."

I now wonder if this ice delta - and others like it along the Antarctic Peninsula (Fig. I) - may not be due to a glacial surge. A surge might be responsible if: (I) All the fragments in the delta have suffered about the same amount of ablation and have, therefore, been formed in one season more or less simultaneously; (2) Ice deltas of this size are not formed yearly but only very occasionally; (3) The volume of glacial ice in the ice delta is greater than that which could be supplied by the normal yearly forward motion of the glacier. If ice deltas are found in front of every tide-water glacier, not all of them can be 